\title{
The Beatitudes Attend the Court: The Princess'S Christian Education in Christine De Pisan'S The Treasure of the Book of the City of Ladies
}

\author{
Maria Ascenção Ferreira Apolonia \\ Doutora em Literatura Portuguesa pela FFLCH/USP, Membro do Instituto Geográfico e Histórico de São \\ Paulo, Brazil
}

*Corresponding Author: Maria Ascenção Ferreira Apolonia, Doutora em Literatura Portuguesa pela FFLCH/USP, Membro do Instituto Geográfico e Histórico de São Paulo, Brazil.

\begin{abstract}
As a consequence of the indissoluble monogamous marriage, women's participation became relevant in the political and cultural scene of the Court, which required "the mastering of experiences" of the princess in several aspects: protocol rules, diplomatic management, social relationships and conflicts related to power, besides some particular prudence to survive and get along with a universe dominated by deals and intrigues, hate and sympathy, all of them moving to the rhythm of political tension and decision taking that characterized the XVth-century Court. To fulfil the demand for a Christian education for the princess, an education appropriate to the historical time and the secular world, the first part of The book of the three virtues focuses on the princess's education, which was more complex and embracing than that of other ladies and peasant women. The education of the latter two ones is dealt with in the two other parts of the book. It is our aim to analyze the insertion of the princess's education in the cultural heritage of the Late Middle Ages: Christine de Pisan's original adaptation of the beatitudes and Christian virtues to the palace life. The treasure of the book of the city of ladies constitutes an exercise of rereading the precepts of both the Gospel and the contemplative life at the level of the circumstances of the active life.
\end{abstract}

Keywords: The XVth-century Court, Christianity, Late Middle Ages.

In this article we analyze the insertion of the princess's education in the historical and cultural context of the Late Middle Ages in order to assess the original adaptation of the beatitudes and Christian virtues to the palace life, including its political dimension. The treasure of the book of the city of ladiesor The book of the three virtues (1406), or, in the Portuguese version, Oespelho de CristinaChristine's mirror - (1518), is made public in a period in which the layman's inclusion and protagonism in the interpretation of the Christian spirituality is accentuated through the publication of books with moral and religious character and princes's images ${ }^{[1]}$ that is, paradigms of spiritual and political behavior for the royal authority. Christine's book is a good example of that. Christine's mirror constitutes an exercise of rereading the precepts of both the Gospel and the contemplative life at the level of the circumstances of the active life. The guidelines for the princess's daily life are derived from that rereading, and they comprise from the organization of her time and expenditure, the relationship with her husband, children and courtiers, to the cultivation of the virtues, particularly the virtue of wisdom and prudence, to delimit and solve conflicts according to the usage, and to discern the risks the princess is exposed to in the mundane environment of the Court in the passage from the $14^{\text {th }}$ to the $15^{\text {th }}$ century.

Christine de Pisan attended the Court in Paris from a very early age, as she was the daughter of King Charles V's(1364-1380)doctor and astrologer, and she witnessed (with consequences for personal life) the unfolding of the political crisis triggered by that king's death, his heir being just 12 years old at the time ${ }^{[2]}$. The tutors' struggle for the ruling divided the relatives into two parties: on one side that of Isabeau of Bavaria, together with Louis d'Orléans, and, on the other side, Jean sans Peur. Financial ambitions and vengeance brought forth a civil war in which each side tried to get the English support $^{[3 a]}$. Contemporary to the Hundred Years' War between France and England, Christine also followed the crisis in which the Christian West fell from 1378 to 1380, because of internal social tensions, economic recession, weight of war, and religious crisis ${ }^{[3 b]}$ To summarize, more than other 
authors who were men and sometimes religious ones and who wrote about princes' images, Christine had a "knowledge of gathered experiences" about the Court, a place that she knew from the backstage, besides having the prerogative of being a woman who wrote to other women, in order to draw the rules of behavior of the princess, who was immersed in an atmosphere of joy and enthusiasm, but also subject to the disputes and turbulence of the Court.

Christine's remarkable erudition and experience led her to be seen as an authority by the medieval public, and that is the reason why The treasure of the city of ladies was well received ${ }^{[4]}$ : three editions in France (1497, 1503, 1536); an old edition in Madrid: O livro das tres vertudes a insinança das damas - The book of the three virtues to teach ladies - from which the first version in Portuguese comes (it is from mid- $15^{\text {th }}$ century). The second Portuguese edition - called $O$ espelho de Cristina (Christine's mirror) - was published in 1518, and there is a new current edition of $\mathrm{it}^{[5]}$. We will use that new edition as the corpus of our analysis. In fact, Christine de Pisan became known in the French academic world and court with her L'épistre au dieu d'amours (1399), a collective letter to the courtiers from Paris. That letter is considered the first literary quarrel proposed by a woman, and its aim was to defend women's dignity against the misogyny in Romance of the rose by Jean de Meun. The literary and cultural quarrel enlarged, and it reverberated from the Parisian court to other kingdoms, besides getting adepts and opponents both in the French university and society throughout the $15^{\text {th }}$ century.

The first part of $O$ espelho de Cristina is dedicated to the princesses and the queen, and it starts greeting the readers, who have the status of listeners, which refers to the medieval collective letters read in public. In fact, in 1406, the access to manuscripts was restricted, so we can probably deduce that it was read collectively, as literary entertainment: "A todas princesas, [scilicet], imperatrizes, Reinhas, duquesas e altas Senhoras que reinam em senhorio sobre a terra dos cristããos, desi em jeeral

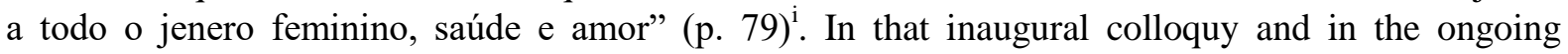
dialogues and letters that constitute The treasure of the book of the city of ladies, we can recognize the link between writing and orality, which is characteristic of the medieval literary genres, and adapted to the ways of entertainment and study in the Late Middle Ages ${ }^{[6]}$.

The beatitude Christine refers explicitly to predispose the princess to listen to is: "Blessed the ones who have the heart of the poor, because theirs is the Kingdom of Heaven" (Mt, 5, 3). Just as St. Augustine and St. Thomas, the author does not relate Christ's words only to the detachment from the material goods, but also to the virtue of humility, which requires the detachment from oneself. In line with Summa Theologica, in The treasure humility is considered an essential condition to moral growth: it removes the obstacles to build up the virtues and it expels pride, making way to God's grace $^{[7 a]}$.Before advocating rules and good habits, Christine stimulates the princess to repent and to convince herself that she is a creature at the service of the Creator and of her subjects too. The author settles an authentic spiritual retreat that excels by evoking the escathological content of the Gospels and by analyzing the inner mood, as the preaching in abbeys and convents. What stands out is the theological depth and the layman's inner life, which can lead the souls to conversion and holiness. ${ }^{[8]}$ The conviction that the average Christian can sanctify himself/herself thanks to state duty enforcement and to exemplary behavior advances in Court and culture nuclei. The treasure is an instance of that ecclesial dynamics that opens up new ways of holiness in civil life, lined up with a lay society more and more active and diversified. Christine mentions King Saint Louis of France and Saint Elizabeth of Hungary specifically as paradigms of authentic Christian life in the exercise of political action.

The treasure also has the merit of revealing details of the palace life, as Christine makes the character/princess use words that she should "say against herself" to grow in humility: " - Oo neicia, sandia, mal avisada! Em pouca d’hora esqueeceste o conhecimento de si mesma! Que pensaste tu? Nom sabes que tu és hu(u)a miserável persoa, criatura sojeita a todas enfermidades e passiõões que

\footnotetext{
i “To all the princesses, that is, empresses, Queens, duchesses and high Ladies who rule over the Christians' land and are entitled for it, from now on to all the female gender, health and love" (adapted from old Portuguese).
} 
corpo mortal pode sofrer! Que avantagem hás tu?"(p. 84) ii . In such a colloquy in which I doubles, contemplating itself as you, there emerges the princess's inner life, transfigured in exclamations full of tension and dramatic character: " - Soberva, rainz de todos os males! [...] per causa de ti soomente, eu som muitas vezes metida em ira, desejando vingança, e me fazes pensar que eu devo de seer temida e preçada sobre todas. E meter todos sob meus pees" (p. 85-86) ${ }^{\text {iii }}$. Under that interlocution, which leads to the knowledge of oneself, we foresee the royals that keep off their Christian identity, in a movement of desacralization and exacerbation of individual interests.

It is made clear to the readers that prestige, power and wealth do not guarantee moral and political success or soul salvation. On the contrary, they assume greater risk and responsibility both in the human and the supernatural level. From the Christian perspective, authority comes from God, and it means service for the ones who depend on it. To rule is to serve (Mt 20, 26-8). In opposition to human tendencies and to absolutist monarchies in formation, the Christian principles are the counterpower, the antidote against inner life tyranny, which produces effects in public life. In consequence of personal detachment, the princess must not indulge in idleness. This is the motto: ora et labora, and it leaves the cloisters to influence time administration in the lay world ${ }^{[9]}$. Preferably, the princess should have the good habit of getting up early, do her personal hygiene and dress by herself, go to the mass, give money to the poor, and assist her children frequently, besides following the spiritual and human formation they are being given. It is also advisable to check her expenditures and her debtors' bills. Even in her idle time, she should choose to do something together with her daughters and Court maidens, to whom she should be an example to be followed. The value of work in its original meaning is highlighted, in opposition to the representation given to it by ancient civilizations, in which it was considered as slaves' occupation. Before the original sin, God had already given Adam and Eve the cultivation and keeping of Eden $(\mathrm{Gn} 2,15)$, as they were collaborators of the creation project.

On the other hand, it is extremely full of meanings the mathematical formula the author proposes to the princess so that she can manage her income well and have a heart just like the poor's:

Ela partirá [suas rendas] em cimquo maneiras: - a primeira parte será pera os pobres; e a segunda pera despesa em sua casa [...]; a terceira pera pagar seus oficiaaes e suas molheres; a quarta será pera dõões d'estranjeiros e doutros que o merecem, fora de suas ordenanças; a quinta será posta em tesouro; e se mais sobejar, será pera seu prazer, assi como roupas e joias e corregimentos ${ }^{\text {iv }}$.

When the authority follows the Christian patterns, private matters are not put over the general welfare. The princess's financial decisions assume a political-social religious connotation which transcends caprices and personal exaltation so that to service the poor is privileged: to attend them, to pay the servants fairly and to grant gifts to the foreigners. Nowadays, in the political and social role assigned to the first lady, we still catch a glimpse of the Christian origin of the appreciation for the needs of the other and of the conscience that the rulers must serve their people, privileging the poor.

However, the author does not exempt herself from legitimating personal expenditure with dresses, jewels and accessories appropriate to a lady of the highest lineage, since it is within the preestablished limits for that purpose. The bounds between the consecrated life and the lay condition are, then, demarcated thanks to the woman-writer's experience who lived together with kings and queens and, at the same time, knew Patristics and the Doctors of the Church. We can notice Christine's effort to reach balance between what is due to a princess and what is superfluous - represented by too much

\footnotetext{
ii Oh, foolish, stupid and misguided creature! You forgot the knowledge about yourself too quickly. What do you think? Don't you know that you are a person full of misery, a creature who is subject to all the diseases and passions a mortal can suffer? What advantages do you have?"

iii Pride, the root of all evil! [...] because of you I am taken by anger, I wish vengeance, and you make me think I must be feared, overvalued above every woman. You make me think I must put everyone under my feet".

iv She will distribute [her income] in five different ways - the first part will be for the poor; the second, for her household expenses [...]; the third part, for her servants and the women who go along with her; the fourth part, for gifts to foreigners and others who deserve it, besides their wages; the fifth part will be put in the treasure; and, if some income is still left, it will be for what pleases her, such as clothes, jewels and adornments" (adapted from old Portuguese).
} 
ostentation and frivolity, to which the Parisian Court tended in the Late Middle Ages, according to what the author herself says, and in the Renaissance ${ }^{[10]}$.

As a natural development from poverty, mercy is also part of the princess's education: "Blessed the merciful, because they will attain mercy" (Mt 5, 7), which Christ complements in the very Mountain Sermon, unveiling God's heart a little: "Be merciful, as your Father is merciful" (Lc 6, 36). Christine sees mercy as the touchstone of charity: "[a princesa] desejará d'haver em si esta fremosa vertude, em tal maneira que será tam piadosa que o mal alheio lhe doerá como o seu próprio"". Then, in an explanation that reverberates the freshness of oral preaching, we almost listen to distant pieces of homilies about works of spiritual mercy: "[...] caridade se estende em muitas maneiras e nom soomente em dar dinheiro da bolsa, mas ajudar, e confortar de palavra e de conselho e de todo outro bem que homem pode fazer" (loc. cit.) ${ }^{\mathrm{vi}}$. And, in another part: "E a booa princesa deve seer bem avisada que compra as obras de misericórdia [...] havendo boos servidores acerca de si e, isso mesmo, boos conselheiros, pera a bem conselharem e darem aa eixucaçom seus boos propósitos" (p. 111) ${ }^{\mathrm{vii}}$. It is so important for the princess to practice charity that the others must alert her to the opportunities that arise in her daily routine. We have to stress that honor and good reputation ("boa nomeada" in old Portuguese), that is, the perception that people have of the princess, is what gives her real authority, and such an authority is consolidated more and more as it reproduces (without any distortion) God's merciful actions in favor of the human being - those actions were unknown in the ancient pagan civilizations.

The princess's mercy passes beyond the frontier of personal sanctification in order to define her essential political role in the relationship between the prince and his people: "E será esta Senhora, per "pura, benina e santa caridade, vogada e medeaneira antre o príncipe, seu marido ou seu filho, se for viúva, e seus povoos e toda sua jente, em todo bem que ela poder ajudar" (p. 105) $)^{\text {viii }}$.The features with which the author builds up the princess's image reveal the projection of the Virgin Mary figure to us, because of the paradigm of moral and political character recommended to the princess: pure, kind, defending and mediatingare qualities attributed to the Holy Mary. They appear in the prayer Hail Holy Queen, present in the Christians' daily life and in their collective imagination from the 11th century.

The queen's mercy thus contribute to guarantee the political exercise of intermediation between the prince and his people, of whom the queen will be a defender and a mediator, just as God's mother (theotókos) ${ }^{[11]}$, queen of the heavenly court, is. In The city of the ladies(2006), another work by Christine de Pisan, the Virgin Mary is invited to live in that utopian village as the queen of the angelical court ${ }^{[12]}$ : There we have an example of how the insertion of the Virgin Mary in the Christian liturgy collaborated with women's appreciation in the political field too.

To have a merciful heart also means to be able to understand the mistakes and flaws of the people you live together with. To validate such a demanding and supernatural prescription Christine quotes St. Gregory: “[...] aquele que nom sabe soportar d'outrem sua impaciencia mostra e testemunha que ele é longe da abastança das virtudes" (p. 104) ${ }^{\mathrm{ix}}$.To call on the ancient philosophers and saints' authority is a common procedure in The treasure, which shows not only the author's erudition, but also the need she feels to use solid arguments, necessary to someone who was against the flow of neopagan trends that were current in the Parisian Court. Those trends were well described in L'épistre au dieu d'amours (1399), with which Christine inaugurated her literary production, as we have already remarked.

\footnotetext{
v"[the princess] will wish she had such a precious virtue, hence she will be so merciful that the evil of others will hurt as if it was hers".

vi، [...] charity manifests itself in different ways and not only in giving one's own money, but also in helping, in comforting with words and advice; and in all the other ways through which men can do good".

viic“And the good princess has to be well guided, so as to fulfill the works of mercy [...] with the help from good servants near her, and, therefore, good counsellors, to advise her well and to ease the accomplishment of the princess's good intentions".

viii "And this Lady will be pure, kind and mediating before the prince, her husband or her son, if she is a widow, and before all her people, in every situation she can help".

ix "The one who cannot stand the other one's impatience shows and witnesses the fact of being far from having virtues in abundance".
} 
Together with mercy, there is another beatitude that is part of the princess's education: "Blessed are the meek, for they will inherit the earth" (Mt 5, 5), which can be completed and explained with some verses from David's Psalm 37: "Wait for the Lord, and keep his way, and he shall exalt thee to inherit the land". Therefore we can interpret "earth/land" in two ways: heavenly Jerusalem, in the eternal level; and place in the world, in the temporal world. Both Christine and St. Thomas refer to Christ, who says He has a "meek and humble heart", to stress the necessary presence of meekness in the Christians' life. For the doctor of the Church, meekness is to restrain wrath, subordinating it to the domain of right reason ${ }^{[7 b]}$. The author's paratopia ${ }^{[13]}$, her status, is to interpret the Doctors of the Church faithfully, and she is the female voice that goes from the temple to the court universe, that addresses the readers' inner side, where it is situated the origin of both good and evil, from the Christian perspective: "[...] a nobre Senhora será tam paciente que... por causa que lhe aconteça nom será movida a impaciencia" (p. 103) ${ }^{x}$. From there she lines up the Christian teachings to the way of being of a princess from the Late Middle Ages, and she guides the princess to conquer meekness and cordiality to deal with her husband, her servants and people the princess dislikes, stressing the reason of such a procedure: "[a persoa] a todos soporta injurias e doestos, com muita paciencia, por amor de Nosso Senhor" (p. 96). ${ }^{\mathrm{xi}}$

It is important not to confuse meekness with passivity, apathy and weakness, as Christine's words show very well:"Esta nobre Senhora, assi desposta per grande constância e per força de coraçom, non

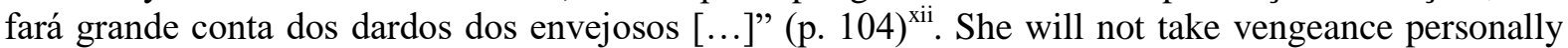
from those ones who behave badly, on the contrary, she will forgive them thanks to the bravery of her inner life, which requires a strong human and spiritual maturation.

We must emphasize that meekness comprises loving hope, a kind of growing wisdom, and a cautious view which counts on time passing by, the result of a confident opening to God's provident action. From such a point of view, harm, envy and slander are never the end: truth will turn up, because God watches over the lives of the righteous. As the psalmist says (and Christine is a mirror of it): "Commit your way to the LORD; trust in him and he will do this. / He will make your righteous reward shine like the dawn, your vindication like the noonday sun" (Psalm 37, 5-6). As Le Goff states, "[...] hope is the main heritage from the Middle Ages to humanity" ${ }^{[14]}$ (our translation). In the $21^{\text {st }}$ century, the hope of supernatural content has fallen into oblivion; that is why Christ's words keep being thoughtprovoking and dense in terms of new information, leading the reader to reflect and to adopt a more critical look as to the roots of uncertainties, subterfuge and perplexities that feature the internal and international political relations of our time. The beatitudes that Christine instituted as life guidelines to the princess and the other women counter in the interlocution between the civilization of interiority and the current world of image and post-truth.

Over the chapters, it stands out a direction to which all the other beatitudes, warnings and practical information converge: "Blessed are the peacemakers, for they will be called children of God" (Mt, 5,9). To build peace up is the full compliance of the propositions in The treasure. And Christine assigns to the woman the protagonism of the fight to install unity. She calls her a peacemaker. According to the view of the medieval world, Christine sees in the woman's nature a greater tendency to sweetness and peace, for men are more impulsive, less merciful, more willing to revenge and less attentive to the dangers and harm that wars can cause. The author agrees with St. Thomas: peace assumes victory over the passions, and it results from the charity that is usually impregnated with sweetness ${ }^{[7 \mathrm{c}]}$. Likewise, in The treasure, charity pervades the woman who promotes harmony, and there is no greater good than to settle peace among enemies; therefore, her works "[...] som de tanto merecimento que nom pode seer mais" (109) $)^{\text {xiii. }}$.

According to such a way of thinking, Christine shows that diplomacy is the political management in which the woman is more successful. She refers to the French History to discuss it: "[...] assi como

\footnotetext{
${ }^{x \text { “ }[. . .] ~ t h e ~ n o b l e ~ L a d y ~ w i l l ~ b e ~ s o ~ p a t i e n t ~ t h a t . . . ~ w h a t e v e r ~ h a p p e n s ~ t o ~ h e r ~ w i l l ~ n o t ~ m a k e ~ h e r ~ b e ~ d r i v e n ~ b y ~}$ impatience".

xic “the person] bears insults patiently for the love of Our Lord”.

${ }^{x i i}$ This noble Lady, who is well prepared, because of her great perseverance and strength of the heart (bravery), will not give much importance to jealous darts".

xiiic“[...] are so worthy that nothing can equal them".
} 
era a Rainha Branca, madre de Sam Luís, a qual sempre trabalhou de poer paz entre el Rei e o povoo [...] a qual cousa é dereito ofício das Rainhas e princesas" (p. 108) ${ }^{\mathrm{xiv}}$. The author makes it clear that the woman has the eyes towards the subjects, the greatest victims of wars: "[...] e a booa Senhora, esguardando estas cousas e havendo piedade da destruiçom do povoo, se trabalhará de meter paz" $(\text { loc. } \text { cit. })^{\mathrm{xv}}$. Christine gives practical information for her to articulate with the prince, the opponents and the counsellors, giving to the princess the words that she must use to guarantee peace: "' $[\ldots] \mathrm{e}$ esguardem bem sobr'esto, ante que comecem oolhando ao mal que se pode seguir'; e como 'boom príncepe deve escusar espargimento de sangue e, em especial, sobre seos sojeitos"' (loc. cit. $)^{\mathrm{xvi}}$. With such warnings, the author, who is also a peacemaker, builds - through the princess's political management - ways to represent the people's aspirations in the instances of power, on which peace depends.

In order to avoid interpersonal or political conflicts, the author suggests the right the princess has to hide what she knows about the enemy, without lying: "E assi usará desto, descreta desimulaçom e prudente cautela, a qual nom crea alguém que seja vicio, ante é vertude, quando é feita a causa de bem e de paz [...]" (p. 140) ${ }^{\text {xvii }}$. By saying so, Christine anticipates the interlocution with those readers who would criticize her for that assertion. If we refer to Summa Theologica, it becomes easier to defend her practice of simulation, because not every representation is bad ${ }^{[7 \mathrm{~d}]}$, since it is not morally necessary to reveal all the truth to everybody in every circumstance; and the Doctor of the Church legitimizes dissimulation in military strategies and in the relationship with enemies ${ }^{[7 \mathrm{e}]}$ Nowadays, we understand the benefits of secrecy in diplomatic relations well, to avoid conflicts and to preserve the national sovereignty. Even the princess's relationships with her husband and her relatives had a political aspect, as the security of the kingdom depended on a solid familiar structure, without any internal disagreement that could deflagrate civil wars and cause the ruin of the kingdom.

We can notice that the family institution in the Christian way served as the basis for the representation of the royal power in the Middle Ages ${ }^{[15]}$, because it was supported by the fidelity to the monogamous and indissoluble marriage, with legitimate heirs. The relation of loyalty between the prince and his subjects was designed from the same logic, since society in the Christian kingdoms is represented as the large family of God's children ${ }^{[16]}$, with the king as governor and guardian. Therefore, the ones who are invested with authority have to promote the conditions to guarantee justice and peace, that is, the necessary stability for the subjects to reach complete earthly and supernatural fulfillment ${ }^{[17]}$. The bond between the temporal and the eternal in the political scope emerges in Christine's warnings for peace: "[a princesa] trabalhará quanto bem poder [...] como tal Guerra seja esquivada [...] chamando Deus em sua ajuda [...] tanto fará, se poder, que hi seja achado caminho de paz" (p. 107) ${ }^{\text {xviii }}$.God is named the prince of peace ${ }^{[18]}$, on whom she calls and of whom she becomes an ambassador. Once again, Christine's experience as an attentive interpreter of the political conflicts of the Late Middle Ages assumes an undeniable weight in the repudiation of war and in the continuous disapproval of it, in favor of peace.

Choosing the beatitudes and the Christian assumptions as references to the princess's intentions and decisions shows that inner life is the privileged scenery of the self-knowledge and of the genesis of the virtues, which protect the rulers against the fascination of the personal ostentation and of the absolute despotism. They remind the rulers that power is the responsibility and the service for the benefit of the people ruled over. From the ecclesial sphere to the Court, the princess's Christian

\footnotetext{
xiv “[...] as Queen Blanche, Saint Louis's mother was. She always endeavored to guarantee the peace between the King and the people [...]. Such an initiative has to be the Queens and princesses' natural obligation".

xv ".. and the good Lady, careful of such things and having compassion on the people's destruction, will endeavor to make peace win".

xvic' $[\ldots]$ and reflect well on [the war], start by considering the evil that follows the war'; and on 'the way the prince must avoid bloodshed, mainly his people's'" (adapted from old Portuguese).

xvii "And so she will make use of discreet concealment and prudent caution, which are not to be thought of as vices, but, rather, as virtues, as they are intended for good and peace [...]" (adapted from old Portuguese).

xviiic“[the princess] will work as much as she can [...] to avoid such a war [...] crying out to God so that He helps her $[\ldots]$ she will do everything at her reach to find a path of peace to this impasse" (adapted from old Portuguese).
} 
education enriched itself with feminine nuance and "acquired knowledge of experiences". The writer took over her role in society, and she optimistically invested in the woman's intelligence and delicacy of feelings in order to build a more righteous world from the princess's deliberations and example. The originality of Christine's Mirror is in her preference for the conciseness of the beatitudes to guide the direction of the woman's management, through the translation of abstract and sacred axioms into the language of financial balance, of power relation game, and of clothes. Therefore, the net of meanings of the beatitudes is enlarged to the extent of the vicissitudes of the female action in the $15^{\text {th }}$ century Court, and it materializes what is expected of the princess's relationship with the servants, the foreigners and between the king and the people. Finally, it is important to remember that the propagation of the princess's education, from Christine's perspective, did not stop in time, rather, it has expanded to the rhythm of the reading of the new editions of her book. Now we are the "princess": we, who participate in this "conversation" between the medieval assumptions and the current strategies to guarantee justice and peace. Can the substrate of medieval values - a layer which favored the formation of Nations - provide us with any revelation about the uncertainties of the national and international political relations of today? Christine de Pisan's work prompts us to think about that.

\section{REFERENCES}

[1] Maria de Lourdes Correia FERNANDES. Espelhos, cartas e guias: casamento e espiritualidade na Península Ibérica 1450-1700. Porto: Instituto de Cultura Portuguesa/Universidade do Porto, 1995.

[2] Charity Cannon WILLARD. Introduction. In: The vision of Christine de Pisan. Cambrigde: D. S. Brewer, 2005; Nadia MARGOLIS. An introduction to Christine de Pizan. Florida: University Press of Florida, 2011.

[3] Simone ROUX. Christine de Pizan: femme de tête, dame de coeur.Paris: Ed. Payot, 1986.

[4] Idem, ibidem.

[5] Charty Cannon WILLARD. The manuscript tradition of the Livre des trois vertus and Christine de Pizan's audience. In: Journal of the History of Ideas. Pennsylvania, v. 27, n. 3, p. 433-444, July/Sept.1966. Retrieved May 2015 from www.jstor.org/stable/2708596?seq=1\# page_scan_tab_contents.

[6] Maria de Lourdes CRISPIM. Introdução. In: Pisan, Christine. O livro das tres virtudes ainsinança das damas.Lisboa: Caminho, 2002. p. 15-31.

[7] Emmanuèle BAUMGARTNER. Moyen Age. In: COUTY, Daniel. Histoire de la littérature française. Paris: Larousse, 2002. p. 5-153.

[8] São Tomás de AQUINO,. (VI, q. 161, a. 5). In: Suma teológica. 2. ed. Caxias do Sul: Sulina Ed./Grafosul, 1980.

[9] Daniel ROPS. A Igreja das catedrais e das cruzadas. São Paulo: Quadrante,1993.

[10] Arnold HAUSER. História social da arte e da literatura. São Paulo: Martins Fontes, 2000.

[11] KOENIGSBERGER, H. G.; MOSSE, George L.; BOWLER, G. Q. Europe in the 16th century. New York: Routledge, 2013. cap. 4, p. 65-82.

[12] The starting point of the cult of the Virgin Mary was the Council of Ephesus in 431., and it was consolidated by the cathedrals dedicated to her from the 12th century. (Jaroslav Pelikan, 2000).

[13] Rectitude prepared a palace in the city of the ladies for Mary to live in. When She enters, every woman has to greet Her as Queen of Heaven (p. 126).

[14] St. Th, IX q. 157, a. 2.

[15] We use paratopia as Dominique Mainguenau defines it: the perspective adopted by the author. In this case, Christine makes religious teachings extended to civil society.

[16] Jacques Le GOFF. Em busca da Idade Média. Rio de Janeiro: Civilização Brasileira, 2011, p. 207.

[17] St. Th. VII q. 29, a.4.

[18] St. Th. VII q. 111 a. 1.

[19] St. Th. VII q. 111 a 1.1.

[20] Jorge BorgesMACEDO. Mulheres e política no século XV português: considerações críticas. Oceanos:mulheres no mar salgado, n. 21, p. 18-20, jan./mar. 1995. Maria Lopes VIEIRA,. Presenças femininas na época dos descobrimentos. n. 21, p. 65-70, jan./mar. 1995.

[21] Jérôme BASCHET. A civilização feudal: do ano mil à colonização da América. São Paulo: Ed. Globo, 2006. 
The Beatitudes Attend the Court: The Princess'S Christian Education in Christine De Pisan'S The Treasure of the Book of the City of Ladies

[22] Daniel ROPS. A Igreja das catedrais e das cruzadas. São Paulo: Quadrante,1993.

[23] JACQUES PHILIPE. A paz interior. São Paulo: Quadrante, 2006. BÍBLIA SAGRADA. 198. ed. São Paulo: Ave Maria, 2012.

Citation: Maria Ascenção Ferreira Apolonia. "The Beatitudes Attend the Court: The Princess'S Christian Education in Christine De Pisan'S The Treasure of the Book of the City of Ladies" International Journal on Studies in English Language and Literature (IJSELL), vol 6, no. 6, 2018, pp. $1-8$. doi:http://dx.doi.org/10.20431/2347-3134.0606001.

Copyright: (C) 2018 Authors. This is an open-access article distributed under the terms of the Creative Commons Attribution License, which permits unrestricted use, distribution, and reproduction in any medium, provided the original author and source are credited. 